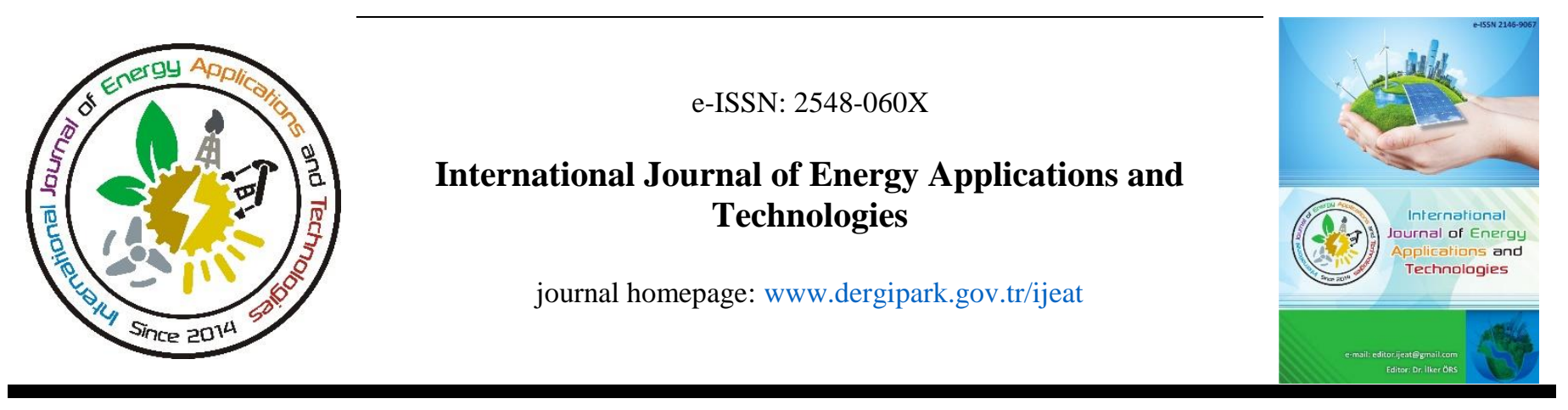

Original Research Article

\title{
Estimation of wind speed with artificial neural networks method for Isparta using meteorological measurement data
}

\author{
Fatih Gemici, Arzu Şencan Şahin* \\ Mechanical Engineering Department, Technology Faculty, Isparta University of Applied Sciences, Isparta, Turkey
}

\author{
ARTICLE INFO \\ * Corresponding author \\ arzusencan@isparta.edu.tr \\ Received March 11, 2020 \\ Accepted May 24, 2021 \\ Published by Editorial Board \\ Members of IJEAT \\ (C) This article is distributed by \\ Turk Journal Park System under \\ the CC 4.0 terms and conditions. \\ doi: 10.31593/ijeat.895362
}

\begin{abstract}
Renewable energy sources are of great importance for our country. Wind energy is a renewable energy source. Today, wind energy is mostly used in electricity generation. The electrical energy to be produced from a wind turbine is directly related to the wind speed in that region. In this study, the wind speed for Isparta between 1st of January 2019, and 31st of December 2019 has been estimated using an artificial neural network (ANN) depending on average air temperature $\left({ }^{\circ} \mathrm{C}\right)$, air pressure $(\mathrm{mb})$, relative humidity $(\%)$, solar radiation $\left(\mathrm{W} / \mathrm{m}^{2}\right)$. MATLAB programming language is used. RMSE (Root-Mean-Square Error) was found to be 6,946427364, and $\mathrm{R}^{2}$ value as 0.9479 , cov coefficient of variation as 0.1609336 . It has been observed that these values are at an acceptable level. Therefore, it has been seen that the artificial neural networks model can be used in wind speed estimation.
\end{abstract}

Keywords: Artificial neural network; Matlab; Wind speed; Prediction

\section{Introduction}

Wind energy is an energy sector with zero harmful gas emissions, unlike the energy sectors based on traditional fossil fuels. Turkey's annual wind energy potential is 100$500 \mathrm{~W} / \mathrm{m}^{2}$. The regions with the highest wind energy are coastal areas such as the Aegean and the Mediterranean. As of 2017, Turkey has 155 licensed wind energy plant and 39 unlicensed wind power plant. According to data from 2018, the top five countries with wind energy installed power are; China, USA, Germany, India and Spain [1].

Wind turbines can only start generating electrical energy at a certain wind speed. A wind turbine generates energy between cut-in and cut-out wind speeds. The cut-in speeds of modern wind turbines are between $2-4 \mathrm{~m} / \mathrm{s}$, nominal speeds $10-15 \mathrm{~m} / \mathrm{s}$ and cut-out speeds between $25-35 \mathrm{~m} / \mathrm{s}$. Correct estimation of the wind speed is essential for estimating the electrical energy that can be produced from the wind [1].
Artificial intelligence methods have been used to predict wind speed, especially recently. Bilgili et al. (2007) used artificial neural networks for the wind speed prediction of target station using reference stations data [2]. Liu et al. (2007) used two ARIMA-ANN and ARIMA-Kalman hybrid methods for wind speed prediction. The performances of both methods have been compared. It has been observed that both methods provide successful performance [3]. Kani and Ardehali (2011) used artificial neural network and Markov chain model to forecast wind speed in very short-term period. It is shown validated that obtained results from ANN-MC model [4]. Liu et al. (2012) developed hybrid model for wind speed forecasting using empirical mode decomposition and artificial neural networks methods. The obtained results show that the performance of the proposed models is highly satisfactory [5]. Sheela and Deepa (2013) used neural network based hybrid computing model to predict wind speed. The results show that the proposed model is very much 
useful for forecasting wind [6]. Hu et al. (2016) used deep neural networks for short-term wind speed prediction. The obtained results have shown the effectiveness of the proposed technique [7]. Filik and Filik (2017) used the artificial neural network to predict wind speed based on local measurements such as temperature and pressure values in Eskişehir [8]. Ramasamy et al. (2015) used the artificial neural network for wind speed forecasting in the mountainous region of India. Temperature, pressure, solar radiation, altitude for model as input data were used [9]. Monfared et al. (2009) used fuzzy logic and artificial neural networks methods for wind speed forecasting. It has been shown that the computational time is reduced by using these methods [10]. Kurbaş (2018) predicted wind speed using statistical methods and artificial neural networks. It is seen that both models can be used reliably for short term wind speed estimation [11]. Dikmen and Örgen (2018) investigated the wind energy potential of the region using wind speed data measured and recorded at a wind measurement station established in Ağlasun region [12]. Köse et al. (2016) estimated daily and hourly average wind speed values using artificial neural networks (ANN) and a new analytical method. The ANN results and the predictions of the analytical method were compared [13]. Kılıç and Arabacı (2015) estimated the future wind speed values of Burdur province by using artificial neural networks (ANN) model [14]. Üneş et al. (2019) used Fuzzy-Fuzzy Logic modeling for wind speed prediction in the Nevada region of the United States [15]. Akarslan and Hocaoğlu (2019) compared the performances of two and multidimensional filters in modeling the wind speed data collected from a Meteorology station located in Afyon Kocatepe University Campus [16]. Altınsoy and Bal (2019) estimated the wind speed for the next year using the month, temperature, pressure, humidity, rainfall and wind speed [17].

\section{Materials and Methods}

\subsection{Artificial neural networks}

Artificial Neural Networks (ANN) is synthetic structures that mimic biological neural networks. ANN is the logical software developed to perform the basic functions of the brain such as learning and generating new information by generalizing, by imitating the working mechanism of the human brain [18]. We can think of ANNs as a black box model that produces output against these inputs by processing the given inputs. First, this black box is subjected to training, and after the training phase, the system reaches a level where it can decide against inputs. ANNs have the ability to learn since they have a training process. This is a feature not found in traditional methods [19].
Artificial neural networks have been developed by influencing the biological nervous system. Biological nerve cells communicate with each other through synapses. A nerve cell sends the information it processes to other cells via its axons. Similarly, artificial nerve cells collect the information coming from outside with a summation function and pass it through the activation function, produce the output and send it to other cells (process elements) over the connections of the network. It has different addition and activation functions. The values of the links that connect artificial neural networks to each other are called weight values. Process elements come together in 3 layers parallel to each other and form a network [20]. These;

- Input layer

- Hidden layer

- Output layer

Figure 1 and Figure 2 show example of simple artificial neural network and working principle of artificial neural network, respectively.

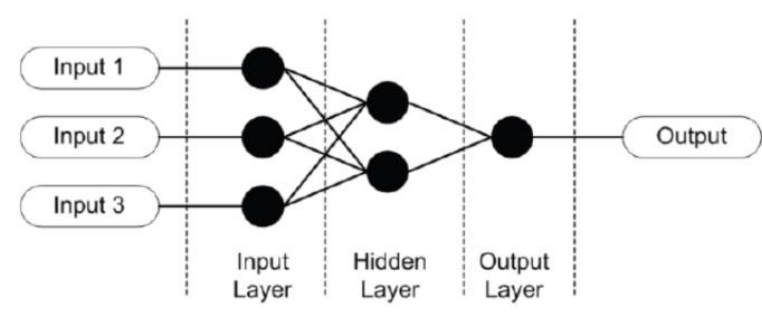

Fig.1. Example of simple artificial neural network [21]

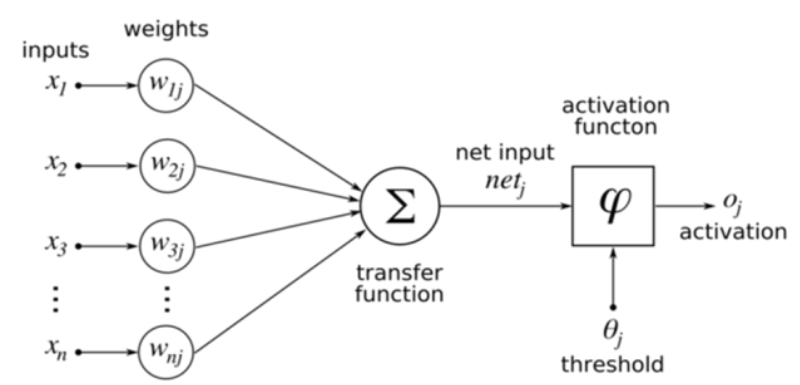

Fig.2. Working principle of ANN

Some statistical methods are used for the accuracy of the artificial neural network model. The Root-Mean-Squared Error (RMSE), the coefficient of multiple determination (R2) and the coefficient of variation (cov) in percent are defined as follows [22]:

$$
\begin{aligned}
& R M S E=\sqrt{\frac{\sum_{m=1}^{n}\left(y_{e, m}-t_{r, m}\right)^{2}}{n}} \\
& R^{2}=1-\frac{\sum_{m=1}^{n}\left(y_{e, m}-t_{r, m}\right)^{2}}{\sum_{m=1}^{n}\left(t_{r, m}-\bar{t}_{r, m}\right)^{2}} \\
& \operatorname{cov}=\frac{R M S}{\left|\bar{t}_{r, m}\right|} \times 100
\end{aligned}
$$


In the equations, ye.m is the estimated value, $t_{r . m}$ is the real value, $\overline{\mathrm{t}}_{\mathrm{r} . \mathrm{m}}$ is the real value average, and $\mathrm{n}$ is the data number.

\subsection{Modeling of the wind energy using ANN}

In this study, wind speed $(\mathrm{m} / \mathrm{s})$ is estimated by using ANN model depending on relative humidity $(\%)$, pressure $(\mathrm{mb})$, air temperature $\left({ }^{\circ} \mathrm{C}\right)$ and solar radiation $\left(\mathrm{W} / \mathrm{m}^{2}\right)$ parameters. In order to train the network, data obtained from the General Directorate of Meteorology (MGM, 2019) were used.

In this study, Matlab neural network toolbox was used. The Levenberg-Marquardt (LM) and scaled conjugate gradient (SCG) algorithms were used. Statistical values such as RMSE, $\mathrm{R}^{2}$ and cov are given in Table 1 for the wind speed. As can be seen in Table 1, the ten-neuron LM algorithm in the hidden layer (LM10) has been found to be the most suitable topology. Figure 3 gives the topology of the artificial neural network created by the neural network toolbox.

Table 1. Statistical results of wind speed prediction

\begin{tabular}{cccc}
\hline $\begin{array}{c}\text { Algorithm } \\
\text { and neurons }\end{array}$ & RMSE & cov & $\mathbf{R}^{2}$ \\
\hline LM3 & 9.04879556 & 0.1619852 & 0.9238 \\
LM4 & 8.05418951 & 0.1578945 & 0.9137 \\
LM5 & 16.59652311 & 0.1498451 & 0.8036 \\
LM6 & 6.84894562 & 0.1722598 & 0.9442 \\
LM7 & 9.01868412 & 0.1205985 & 0.9241 \\
LM8 & 10.87210069 & 0.1386549 & 0.9315 \\
LM9 & 6.241109681 & 0.1491036 & 0.9410 \\
LM10 & $\mathbf{6 . 9 4 6 4 2 7 3 6 4}$ & $\mathbf{0 . 1 6 0 9 3 3 6}$ & $\mathbf{0 . 9 4 7 9}$ \\
LM11 & 7.499541231 & 0.1927569 & 0.9320 \\
LM12 & 6.847212191 & 0.1996314 & 0.9468 \\
SCG3 & 20.48945120 & 0.01768456 & 0.7665 \\
SCG4 & 20.59584513 & 0.01525689 & 0.7647 \\
SCG5 & 21.49845412 & 0.01789654 & 0.7735 \\
SCG6 & 21.54951235 & 0.01795216 & 0.7751 \\
\hline
\end{tabular}

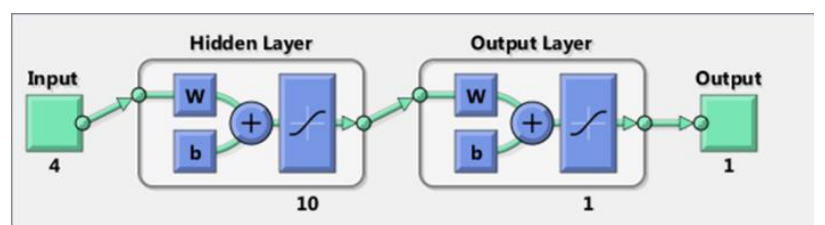

Fig.3. Topology created by the neural network toolbox

The decrease in mean square error (MSE) during the training process of this topology is given in Figure 4.

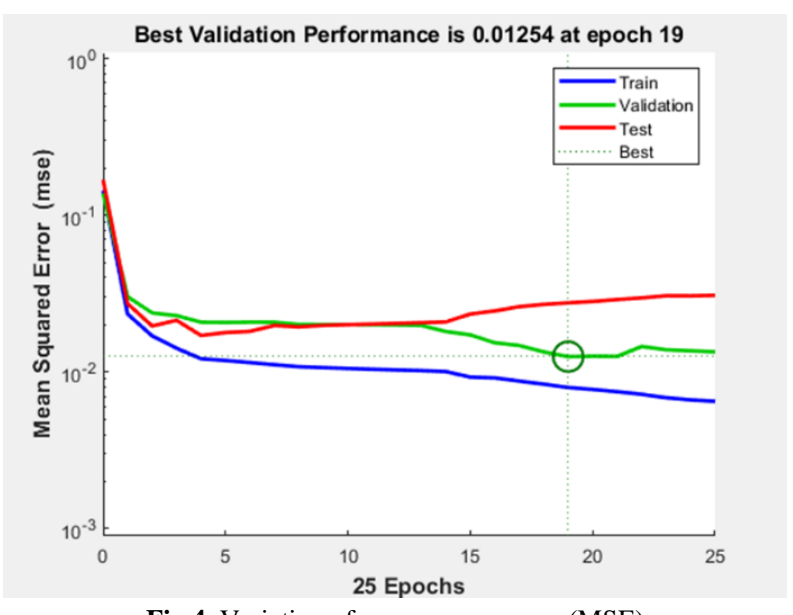

Fig.4. Variation of mean square error (MSE)

\section{Result and Discussion}

In this study, the wind speed for Isparta between 1st of January 2019, and 31st of December 2019 has been estimated using an artificial neural network (ANN) depending on average air temperature $\left({ }^{\circ} \mathrm{C}\right)$, air pressure $(\mathrm{mb})$, relative humidity $(\%)$, solar radiation $\left(\mathrm{W} / \mathrm{m}^{2}\right)$.

Table 4 presents a comparison between the actual wind speed and the wind speed predicted by ANN. As given in Table 4, the percentage error value was found to be $\% 5.21$, and it is seen that these error values are at an acceptable level.

In Figure 5, the daily actual wind speed of July 2019 and the estimated wind speed values with ANN are compared. It is seen that the actual and predicted values are very close to each other.

Table 4. Comparison of actual and estimated wind speed values with ANN and error values

\begin{tabular}{|c|c|c|c|c|c|c|c|}
\hline $\begin{array}{c}\text { Average } \\
\text { temperature }\left({ }^{\circ} \mathbf{C}\right)\end{array}$ & $\begin{array}{c}\text { Air Pressure } \\
(\mathbf{m b})\end{array}$ & $\begin{array}{c}\text { Relative } \\
\text { humidity } \mathbf{( \% )}\end{array}$ & $\begin{array}{c}\text { Solar radiation } \\
\left(\mathbf{W} / \mathbf{~ m}^{\mathbf{2}}\right)\end{array}$ & $\begin{array}{c}\text { Actual wind } \\
\text { speed (m/sn) }\end{array}$ & $\begin{array}{c}\text { ANN wind } \\
\text { speed }(\mathbf{m} / \mathbf{s n})\end{array}$ & $\begin{array}{c}\text { Error } \\
\text { Percentage } \\
\text { error(\%) }\end{array}$ \\
\hline 8 & 993.6 & 84.5 & 1635.8 & 6.6 & 6.3 & 0.3 & 5.21 \\
\hline 14.9 & 1016.7 & 73 & 5316.9 & 11.3 & 10.7 & 0.6 & 5.21 \\
\hline 18.5 & 1017.6 & 72.5 & 7466.2 & 5.3 & 5.0 & 0.3 & 5.21 \\
\hline 16.9 & 1021.5 & 73 & 7574.8 & 5.3 & 5.0 & 0.3 & 5.21 \\
\hline 23.1 & 1014.5 & 66.5 & 7179.6 & 6.2 & 5.9 & 0.3 & 5.21 \\
\hline 23.9 & 1013.8 & 66 & 7321.1 & 3.5 & 3.3 & 0.2 & 5.21 \\
\hline 9 & 1034.8 & 70.5 & 4955.5 & 6.4 & 6.1 & 0.3 & 5.21 \\
\hline 15.8 & 1028.8 & 68.5 & 4738.4 & 6 & 5.7 & 0.3 & 5.21 \\
\hline 7.1 & 1009.1 & 81 & 1681.2 & 3.6 & 3.4 & 0.2 & 5.21 \\
\hline 3.7 & 1034.7 & 84.5 & 1550.4 & 6.2 & 5.9 & 0.3 & 5.21 \\
\hline
\end{tabular}




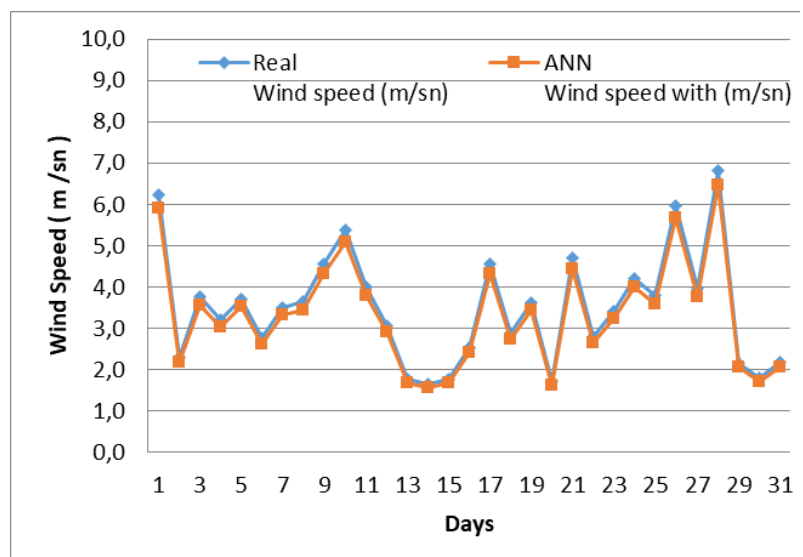

Fig.5. Comparison of daily actual and predicted wind speed values with ANN for July 2019

\section{Conclusion}

Wind speed estimation will provide us great convenience especially for the calculation of wind speed in mountainous areas. Significant labor savings will be achieved in the lands. In this study, the wind speed for Isparta between 1st of January 2019, and 31st of December 2019 has been estimated using an artificial neural network (ANN) depending on average air temperature $\left({ }^{\circ} \mathrm{C}\right)$, air pressure $(\mathrm{mb})$, relative humidity $(\%)$, solar radiation $\left(\mathrm{W} / \mathrm{m}^{2}\right)$. Estimated values with ANN method and actual values were compared. As a result of the statistical analysis, the RMSE error value was found as 6.946427364 , the $R^{2}$ value as 0.9479 , and the cov variation coefficient as 0.1609336 . These values were found to be at an acceptable level. In addition, the highest percentage error value was found to be $5.21 \%$ and the comparative graphs of daily actual and estimated wind speed values with ANN are given. As a result, it is seen that ANN model can be used successfully in estimating the wind speed.

\section{ORCID}

F. Gemici

A. Şencan Şahin

iD $0000-0003-3959-0864$ 0000-0001-8519-4788

\section{References}

[1] https://www.enerjiportali.com/ruzgar-enerjisi-nedir/ (10 January 2021.)

[2] ilgili, M., Sahin, B., Yasar, A. 2007. Application of artificial neural networks for the wind speed prediction of target station using reference stations data. Renewable Energy, 32(14), 2350-2360.

[3] Liu, H., Tian, H. Q., Li, Y. F. 2012. Comparison of two new ARIMA-ANN and ARIMA-Kalman hybrid methods for wind speed prediction. Applied Energy, 98, 415-424.
[4] Kani, S. P., Ardehali, M. M. 2011. Very short-term wind speed prediction: A new artificial neural networkMarkov chain model. Energy Conversion and Management, 52(1), 738-745.

[5] Liu, H., Chen, C., Tian, H. Q., Li, Y. F. 2012. A hybrid model for wind speed prediction using empirical mode decomposition and artificial neural networks. Renewable energy, 48, 545-556.

[6] Sheela, K. G., Deepa, S. N. 2013. Neural network based hybrid computing model for wind speed prediction. Neurocomputing, 122, 425-429.

[7] u, Q., Zhang, R., Zhou, Y. 2016. Transfer learning for short-term wind speed prediction with deep neural networks. Renewable Energy, 85, 83-95.

[8] Filik, Ü. B., Filik, T. 2017. Wind speed prediction using artificial neural networks based on multiple local measurements in Eskisehir. Energy Procedia, 107, 264269.

[9] Ramasamy, P., Chandel, S. S., Yadav, A. K. 2015. Wind speed prediction in the mountainous region of India using an artificial neural network model. Renewable Energy, 80, 338-347.

[10] Monfared, M., Rastegar, H., Kojabadi, H. M. 2009. A new strategy for wind speed forecasting using artificial intelligent methods. Renewable energy, 34(3), 845-848.

[11] Kırbaş, İ. 2018. İstatistiksel metotlar ve yapay sinir ağları kullanarak kısa dönem çok adımlı rüzgâr hızı tahmini. Sakarya University Journal of Science, 22(1), 24-38.

[12] Dikmen, E., Örgen, F. K. 2018. Ağlasun Bölgesi İçin Rüzgâr Hızı Tahmini ve En Uygun Türbin Tespiti. Niğde Ömer Halisdemir Üniversitesi Mühendislik Bilimleri Dergisi, 7(2), 871-879.

[13] Köse, B., Atila, Ü., Güneşer, M. T., Recebli, Z. 2016. An Approach to Estimate Hourly \& Daily Mean Wind Speed and Comparison with Artificial Neural Network. In 10th International Clean Energy Symposium (pp. 2426).

[14] Kılıç, B., Arabac1, E. 2015. Burdur İli Gelecekteki Rüzgâr Hızı Değerlerinin Yapay Sinir Ağları Metodu ile Tahmini. Dumlupınar Üniversitesi Fen Bilimleri Enstitüsü Dergisi, (2015 Özel Sayıs1), 45-50.

[15] Üneş, F., Kasal, D., Taşar, B. 2019. Meterolojik Ölçüm Verilerini Kullanarak Mamdani-Bulanık Mantık Yöntemi ile Rüzgar Hızının Tahmini. Osmaniye Korkut Ata Üniversitesi Fen Bilimleri Enstitüsü Dergisi, 2(1), 97-104.

[16] Akarslan, E., Hocaoğlu, F. O. 2019. Rüzgar Hızı Verilerinin Yeni Bir Yaklaşım ile Modellenmesi. Afyon Kocatepe Üniversitesi Fen ve Mühendislik Bilimleri Dergisi, 19(1), 121-128. 
[17] Altınsoy, M., Bal, G. 2019. Uzun dönem rüzgâr hizi tahmininde yapay sinir ağlarinin kullanimi ve performans İncelemesi. Mesleki Bilimler Dergisi (MBD), 8(1), 21-28.

[18] Egrioglu, E., Aladag, C. H., Yolcu, U., Uslu, V. R., Basaran, M. A. 2009. A new approach based on artificial neural networks for high order multivariate fuzzy time series. Expert Systems with Applications, 36(7), 10589-10594.

[19] Öztopal, A., Şen, Z. 2011. Kısa vadeli yă̆ı̧s modellemesi için yapay sinir ağları yaklaşımı. İTÜDERGİSİ/d, 8(1).

[20] Öztemel, E. 2003. Yapay sinir ağlari. PapatyaYayincilik, Istanbul.

[21] Suzuki, K. (Ed.). 2011. Artificial neural networks: methodological advances and biomedical applications. BoD-Books on Demand.

[22] Bechtler, H., Browne, M. W., Bansal, P. K., Kecman, V. 2001. New approach to dynamic modelling of vapour-compression liquid chillers: artificial neural networks. Applied Thermal Engineering, 21(9), 941953. 